\title{
Bifidobacterium mongoliense sp. nov., from airag, a traditional fermented mare's milk product from Mongolia
}

\author{
Correspondence \\ Koichi Watanabe \\ koichi-watanabe@yakult.co.jp
}

\author{
Koichi Watanabe, ${ }^{1}$ Hiroshi Makino, ${ }^{1}$ Masae Sasamoto, ${ }^{1}$ Yuko Kudo, ${ }^{1}$ \\ Junji Fujimoto ${ }^{1}$ and Shirchin Demberel $^{2}$
${ }^{1}$ Yakult Central Institute for Microbiological Research, 1796 Yaho, Kunitachi, Tokyo 186-8650, Japan \\ ${ }^{2}$ Mongolian State University of Agriculture, Zaisan-53, MSUA Ulaanbaatar 210153, Mongolia
}

\begin{abstract}
Two novel micro-organisms, designated strains YIT $10443^{\top}$ and YIT 10738, were isolated from airag, a traditional fermented mare's milk from Mongolia. The two strains were Gram-positivestaining, non-motile, asporogenous, catalase-negative, facultatively anaerobic rods of various shapes. Comparative analyses of $16 \mathrm{~S}$ rRNA and ClpC ATPase $(c / p C)$ gene sequences and the presence of fructose-6-phosphate phosphoketolase (F6PPK) demonstrated that the novel strains were members of the genus Bifidobacterium. On the basis of 16S rRNA gene sequence similarity, the type strains of Bifidobacterium minimum (96.6\%) and Bifidobacterium psychraerophilum $(95.7 \%)$ were the closest neighbours of the novel strains, and DNA-DNA reassociation values with these strains were found to be lower than $15 \%$. The phenotypic and genotypic features demonstrated that the two strains represent a single, novel Bifidobacterium species, for which the name Bifidobacterium mongoliense sp. nov. is proposed. The type strain is YIT $10443^{\top}$ (=JCM $15461^{\top}=$ DSM $21395^{\top}$ ).
\end{abstract}

Bifidobacteria are Gram-positive, anaerobic, non-motile, non-spore-forming bacteria that are typically found in the intestinal tract of humans and animals (Moore \& Holdeman, 1974; Scardovi \& Zani, 1974; Finegold et al., 1983; Scardovi, 1986; Matsuki et al., 2004; Simpson et al., 2004). Currently, 29 species and 9 subspecies have been described. It has been suggested that Bifidobacterium species are important for maintaining general health, and many attempts have been made to increase the populations of bifidobacteria in the intestinal tract of humans and animals by supplying certain bifidobacterial strains as probiotics (Fuller, 1989; Kitajima et al., 1997; Lee et al., 1999). Bifidobacteria have been isolated not only from the gastrointestinal tracts of humans and animals but also from

Abbreviations: F6PPK, fructose-6-phosphate phosphoketolase; LAB, lactic acid bacteria; RAPD, randomly amplified polymorphic DNA.

The GenBank/EMBL/DDBJ accession numbers for the $16 \mathrm{~S}$ rRNA gene sequences of strains YIT 10443 ${ }^{\top}$, YIT 10738, B. minimum YIT $4097^{\top}$ and B. psychraerophilum YIT $11814^{\top}$ are AB433856, AB433857, $A B 437350$ and $A B 437351$, respectively, and those for the clpC gene sequences of strains YIT 10443 ${ }^{\top}$, YIT 10738, B. minimum YIT $4097^{\top}$ and B. psychraerophilum YIT $11814^{\top}$ are AB433858-AB433861, respectively.

RAPD-PCR fingerprints and scanning electron micrographs of the novel strains and a maximum-likelihood 16S rRNA gene sequence-based tree are available as supplementary material with the online version of this paper. environmental materials such as sewage (Scardovi \& Trovatelli, 1974) and an anaerobic digester (Dong et al., 2000).

During a study on the diversity of lactic acid bacteria $(\mathrm{LAB})$ in airag (fermented mare's milk) and tarag (fermented milk of cows, yaks, goats or camels), traditional fermented milk products from Mongolia, bifidobacterial strains YIT $10443^{\mathrm{T}}$ and YIT 10738 were isolated from two of 22 airag samples, which were collected in the Mongolian provinces of Umnugobi and Uburhangai, respectively (Watanabe et al., 2008). Samples were serially diluted with sterile saline $(0.85 \% \mathrm{NaCl})$ before being inoculated onto modified MRS agar (glucose replaced with $1 \%$ lactose) supplemented with $0.001 \%$ sodium azide and $0.001 \%$ cycloheximide and incubated anaerobically at $30{ }^{\circ} \mathrm{C}$ for 3 days in an anaerobic chamber (Coy Laboratory Products; atmosphere comprising 88:5:7 $\left.\quad \mathrm{N}_{2} / \mathrm{CO}_{2} / \mathrm{H}_{2}\right)$. Pinpoint colonies were found initially among colonies of $\mathrm{LAB}$ on the surface of the agar plates. Cell counts of bifidobacterial strains YIT $10443^{\mathrm{T}}$ and YIT 10738 in airag samples were $7.74 \log _{10}$ c.f.u. $\mathrm{ml}^{-1}$ and $7.60 \log _{10}$ c.f.u. $\mathrm{ml}^{-1}$, respectively. The strains were suspended in nutrient broth (BD Difco) containing $10 \%(\mathrm{v} / \mathrm{v})$ DMSO and stored at $-80{ }^{\circ} \mathrm{C}$.

This study presents the morphological, biochemical and molecular characterization of strains YIT $10443^{\mathrm{T}}$ and YIT 10738. Bifidobacterium minimum YIT $4097^{\mathrm{T}}$ and 
Bifidobacterium psychraerophilum YIT $11814^{\mathrm{T}}$ were obtained from the culture collection of the Yakult Central Institute (YIT) and were used as reference strains. For further experiments, strains were cultivated and maintained in GAM broth (Nissui) supplemented with $1 \%$ lactose (modified GAM broth, $\mathrm{pH} 6.8$ ) at $30{ }^{\circ} \mathrm{C}$ for 1 or 2 days, unless indicated otherwise.

Chromosomal DNA used as a template for randomly amplified polymorphic DNA (RAPD) typing and 16S rRNA gene sequence amplification was prepared from the isolates according to the method of Watanabe et al. (2008). For discrimination of the isolates, RAPD fingerprinting was performed by a method described previously (Chao et al., 2008). Primers A $\left(5^{\prime}\right.$-CCGCAGCCAA- $\left.3^{\prime}\right)$, B $\left(5^{\prime}\right.$ AACGCGCAAC- $\left.3^{\prime}\right)$ and C (5'-GCGGAAATAG-3') were used. The two strains had different RAPD profiles (see Supplementary Fig. S1, available in IJSEM Online).

The partial 16S rRNA genes of strains YIT $10443^{\mathrm{T}}$ and YIT 10738 were amplified by PCRs using universal primers BI8F (5'-GGGTTYCGATTCTGGCTCAGGATG-3') and 15R (5'-AAGGAGGTGATCCARCCGCA-3') (Miyake et al., 1998). Partial ClpC ATPase (clpC) genes of the two strains were amplified using primers BClpC-F (5'ATCGCSGARACBATYGAGA) and BClpC-R (5'ATRATGCGCTTGTGCARYT-3'). These primers were designed from the consensus sequence of the $c l p C$ genes of Bifidobacterium adolescentis ATCC 15704 (GenBank accession no. AY722389), B. animalis subsp. animalis ATCC $25527^{\mathrm{T}}$ (AY722380), B. breve UCC 2003 (AY722390), B. dentium JCM 1195 ${ }^{\mathrm{T}}$ (AY722387), B. longum subsp. infantis JCM $1222^{\mathrm{T}}$ (AY722381), B. pseudolongum subsp. globosum JCM 5820 ${ }^{\mathrm{T}}$ (AY722386), B. pullorum LMG 21816 (AY722383) and B. thermophilum JCM $1207^{\mathrm{T}}$ (AY722384). The PCR mixture $(25 \mu \mathrm{l})$ contained $10 \mathrm{mM}$ Tris/ $\mathrm{HCl} \quad(\mathrm{pH} 8.3), \quad 50 \mathrm{mM} \mathrm{KCl}$, $200 \mu \mathrm{M}$ of each dNTP, $1 \mathrm{mM} \mathrm{MgCl} 2,1 \mu \mathrm{g}$ BSA, $0.5 \mathrm{U}$ Taq DNA polymerase (Takara Bio Inc.), $0.1 \mu \mathrm{M}$ each primer and $10 \mathrm{ng}$ template DNA. The amplification program consisted of an initial heating step at $94{ }^{\circ} \mathrm{C}$ for $2 \mathrm{~min}, 30$ cycles of $94{ }^{\circ} \mathrm{C}$ for $20 \mathrm{~s}, 55{ }^{\circ} \mathrm{C}$ for $30 \mathrm{~s}$ (for the $16 \mathrm{~S}$ rRNA gene) or $58{ }^{\circ} \mathrm{C}$ for $20 \mathrm{~s}$ (for the $c l p C$ gene) and $72{ }^{\circ} \mathrm{C}$ for $20 \mathrm{~s}$ and a final extension step at $72{ }^{\circ} \mathrm{C}$ for $3 \mathrm{~min}$. The PCR-amplified 16S rRNA and $c l p C$ genes from these strains were purified using a Montage PCR Filter unit (Millipore) according to the manufacturer's instructions. Cycle-sequencing reactions were performed using an $\mathrm{ABI}$ PRISM Big Dye Terminator v. 3.1 cycle-sequencing kit (Applied Biosystems) and an ABI PRISM 3130xl Genetic Analyzer (Applied Biosystems).

16S rRNA gene sequences of strains YIT $10443^{\mathrm{T}}$ and YIT 10738 were determined by the methods described previously (Chao et al., 2008). The closest known relatives of the strains were determined by using FASTA, and sequences of closely related species were retrieved from DDBJ/ GenBank/EMBL databases. Multiple alignment of the sequences was carried out with the CLUSTAL_X program version 1.82 (Thompson et al., 1997). Approximately $1450 \mathrm{bp}$ of the 16S rRNA gene sequences of the strains and related species were used for constructing phylogenetic trees with the neighbour-joining method (Saitou \& Nei, 1987). The statistical reliability of the tree was evaluated by bootstrap analysis of 1000 replicates (Felsenstein, 1985) and the tree topology was also confirmed with the maximum-parsimony (Fitch, 1971) and maximum-likelihood (Cavalli-Sforza \& Edwards, 1967) methods, by using PHYLIP version 3.67 (Felsenstein, 2007). By using the EzTaxon program (Chun et al., 2007), the similarities between the 16S rRNA gene sequences of YIT $10443^{\mathrm{T}}$ and YIT 10738 was $99.9 \%$. The sequence similarity between strain YIT $11443^{\mathrm{T}}$ and its closest neighbours, B. minimum YIT $4097^{\mathrm{T}}$, B. psychraerophilum YIT $11814^{\mathrm{T}}$ and B. subtile DSM $20096^{\mathrm{T}}$, was $96.6,95.7$ and $95.8 \%$, respectively. The novel strains formed a subcluster with $B$. minimum, $B$. psychraerophilum and B. subtile on the basis of neighbourjoining analysis (Fig. 1). Similar topologies were obtained by the maximum-parsimony (data not shown) and maximumlikelihood (Supplementary Fig. S2) methods. The similarities among $c l p C$ gene sequences (about $470 \mathrm{bp}$ ) of strains YIT $10443^{\mathrm{T}}$ and YIT 10738 and their closest relatives $B$. minimum YIT $4097^{\mathrm{T}}$, B. psychraerophilum YIT $11814^{\mathrm{T}}$ and B. subtile LMG $11597^{\mathrm{T}}$ ranged from 81.8 to $85.8 \%$. The similarity between the $c l p C$ gene sequences of YIT $10443^{\mathrm{T}}$ and YIT 10738 was $99.4 \%$. Interspecies gaps within the genus Bifidobacterium based on clpC gene sequences normally exceed $10-15 \%$ ( $81 \%$ mean similarity; Ventura et al., 2006), which suggested that these two strains are members of a novel Bifidobacterium species. On the basis of neighbour-joining analysis of $c l p C$ gene sequences, the novel strains did not belong to any existing recognized species and formed a distinct subcluster with B. subtile (Fig. 2).

For determination of DNA-DNA relatedness and DNA $\mathrm{G}+\mathrm{C}$ content, chromosomal DNA was extracted according to the method of Marmur (1961). DNA-DNA reassociation analyses were performed according to the microdilution well technique, using photobiotin for DNA labelling (Ezaki et al., 1989). Reciprocal hybridization experiments were performed for each pair of strains at $50{ }^{\circ} \mathrm{C}$ for $15 \mathrm{~min}$ in the presence of $50 \%$ formamide. DNA-DNA relatedness values between strains YIT $10443^{\mathrm{T}}$ and YIT 10738 were $72-$ $80 \%$, which showed that these two strains belonged to the same taxon, whereas the relatedness of YIT $10443^{\mathrm{T}}$ to $B$. minimum YIT $4097^{\mathrm{T}}$ and B. psychraerophilum YIT $11814^{\mathrm{T}}$ was $11-15 \%$ and $5-8 \%$, respectively. The hybridization values with the reference strains were well below the $70 \%$ cut-off value that is recommended to separate species (Wayne et al., 1987). To assess DNA base composition, DNA was degraded enzymically into nucleosides as described previously (Mesbah et al., 1989) and then separated by HPLC. The DNA G $+\mathrm{C}$ contents of strains YIT $10443^{\mathrm{T}}$ and YIT 10738 were 61.1 and $61.9 \mathrm{~mol} \%$.

Morphological, cultural and biochemical testing according to standard techniques was performed at $30{ }^{\circ} \mathrm{C}$ unless otherwise stated. Morphological characteristics of strains 


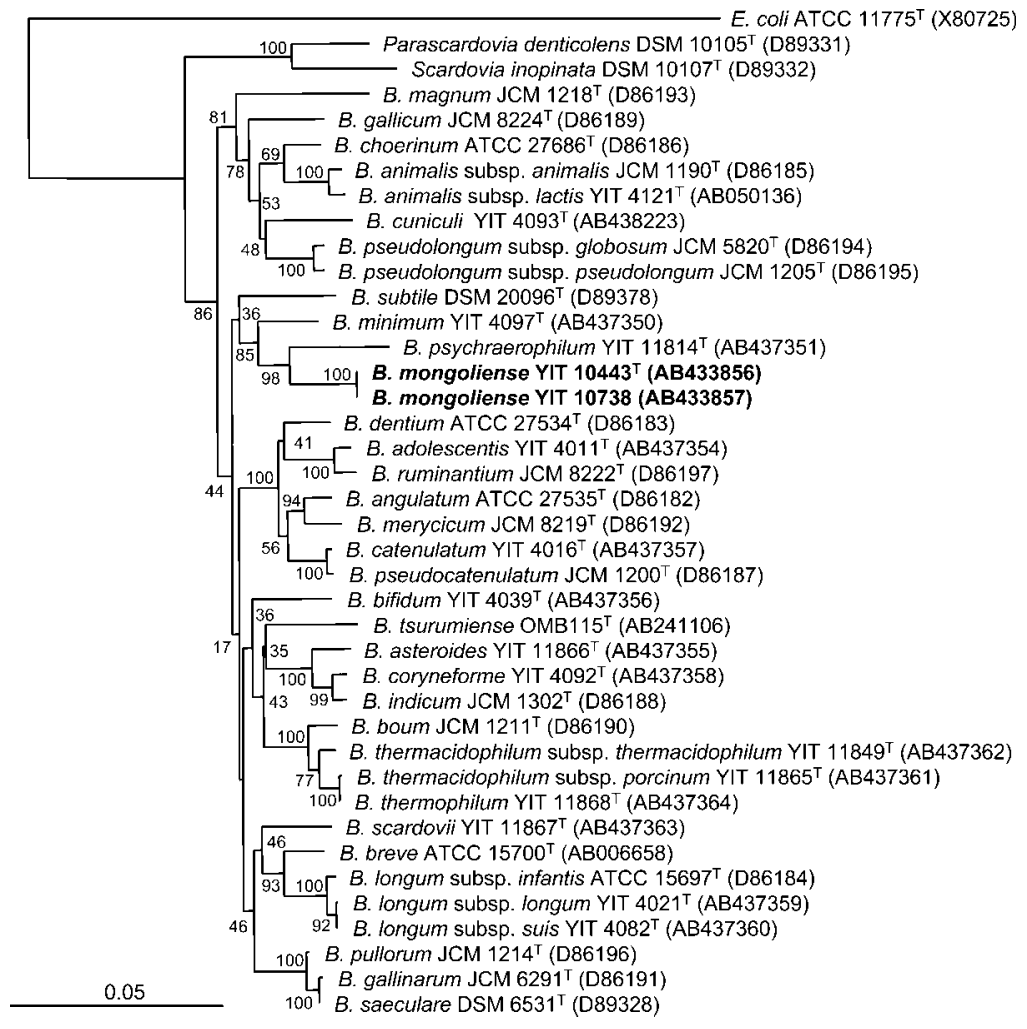

Fig. 1. Phylogenetic tree based on $16 \mathrm{~S}$ rRNA gene sequences showing the relationship of strains YIT $10443^{\top}$ and YIT 10738 with closely related species. The tree was constructed by the neighbour-joining method on the basis of a comparison of approximately 1460 positions, and the sequence of Escherichia coli ATCC $11775^{\top}$ was used as an outgroup. Bootstrap values (\%) based on 1000 replications are given at nodes. Bar, $5 \%$ sequence divergence.

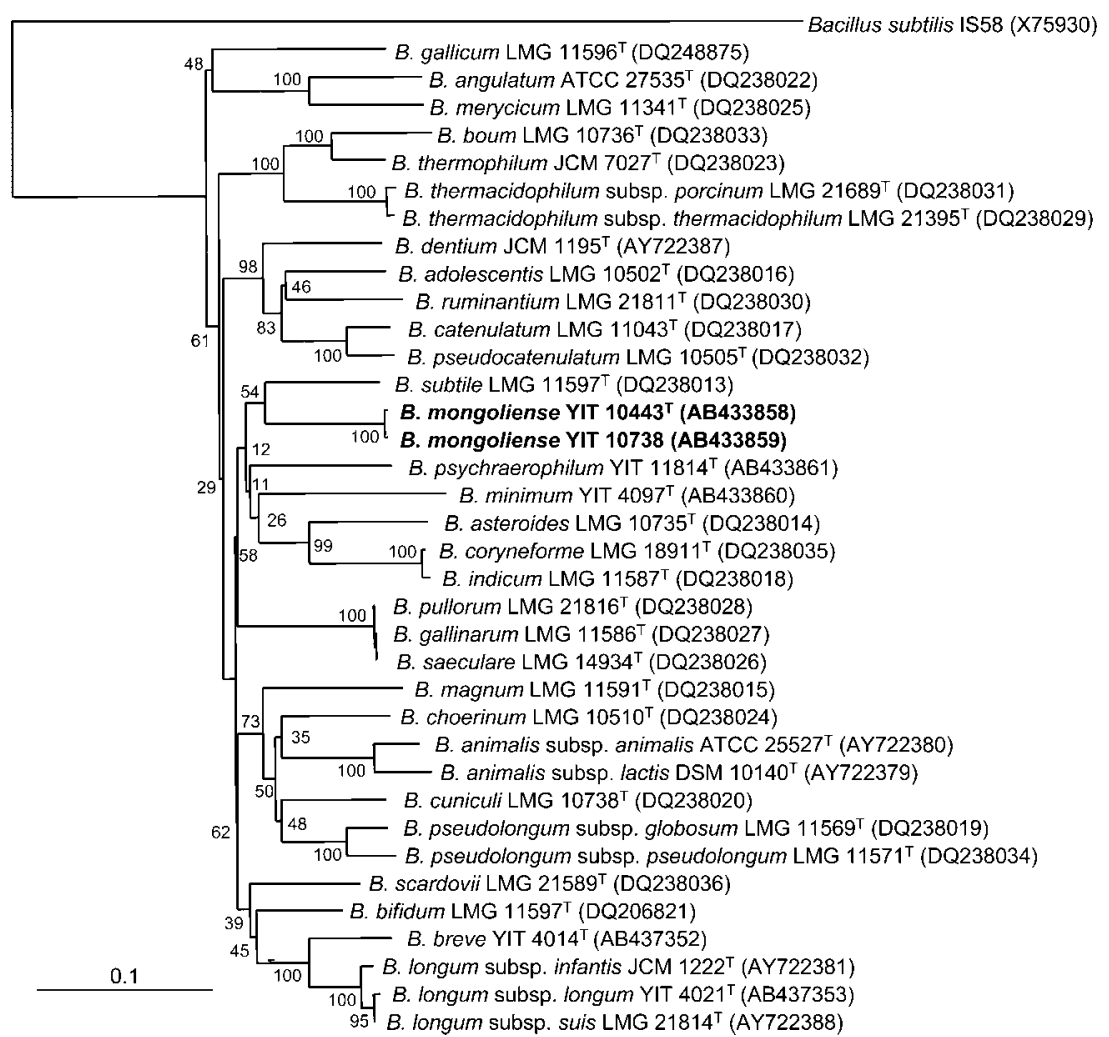

Fig. 2. Phylogenetic tree based on $c / p C$ gene sequences showing the relationship of the novel strains isolated from airag with closely related species. The tree was constructed by the neighbour-joining method on the basis of a comparison of approximately 470 positions, and the sequence of Bacillus subtilis IS58 was used as an outgroup. Bootstrap values (\%) based on 1000 replications are given at nodes. Bar, 10\% sequence divergence. 
YIT $11443^{\mathrm{T}}$ and YIT 11738 were determined by using a scanning electron microscope. The strains were cultured in modified GAM broth (supplemented with $1 \%$ lactose) at $30{ }^{\circ} \mathrm{C}$ for 1-2 days under anaerobic conditions. After culturing, cells were washed with $0.05 \mathrm{M}$ phosphate buffer (pH 7.0), fixed with $2.5 \%$ glutaraldehyde for $1 \mathrm{~h}$ at $4{ }^{\circ} \mathrm{C}$, post-fixed with $1 \%$ osmium tetroxide for $1 \mathrm{~h}$ at $4{ }^{\circ} \mathrm{C}$, dehydrated with a series of increasing ethanol concentrations (twice at 50, 70, 80, 90, 95 and $100 \%$ for $20 \mathrm{~min}$ each) and soaked twice in 3-methyl butyl acetate for $20 \mathrm{~min}$. The prepared cells were subsequently criticalpoint-dried in a critical point dryer (model HCP-2; Hitachi), sputter-coated with gold (model SC-701C-MC; SANYU Electron) and observed with a scanning electron microscope (model S-3400N; Hitachi). Scanning electron micrographs of cells of strains YIT $10443^{\mathrm{T}}$ and YIT 10738 are shown in Supplementary Fig. S3. Gram staining and catalase activity were determined by using cells grown on modified GAM agar at $30{ }^{\circ} \mathrm{C}$ for 2 days. Motility was tested in modified GAM soft agar $(0.15 \%)$. Carbohydrate fermentation tests were carried out by using the API 50CHL system (bioMérieux) in triplicate according to the manufacturer's instructions with some modification. Cells from agar plates were suspended in CHL broth supplemented with $0.025 \%$ cysteine hydrochloride, inoculated onto the test strips and incubated in an anaerobic chamber at $30{ }^{\circ} \mathrm{C}$ for 5 days. F6PPK activity was determined according to the method described by Scardovi (1986). Cell-wall peptidoglycan was prepared and hydrolysed according to the method of Schleifer \& Kandler (1972). Cell-wall amino acids were analysed by HPLC (Alliance 2695 HPLC system; Waters) equipped with a fluorescence detector (model 474; Waters) and an AccQ-Tag column $(3.9 \times 150 \mathrm{~mm}$; Waters) and AccQ-Fluor reagent kit (6-

Table 1. Major differential characteristics between strains YIT $10443^{\top}$ and YIT 10738 and genetically closely related bifidobacteria

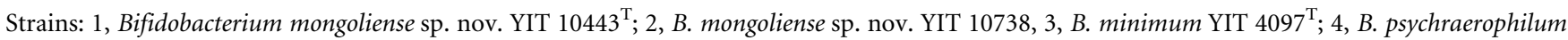
YIT $11814^{\mathrm{T}}$. Data were obtained in this study. All four strains produced acid from D-glucose, maltose, methyl $\alpha$-D-glucopyranoside, turanose and sucrose. None of the strains produced acid from glycerol, erythritol, D-arabinose, D- or L-xylose, D-adonitol, methyl $\beta$-D-xylopyranoside, Lrhamnose, dulcitol, inositol, D-mannitol, D-sorbitol, methyl $\alpha$-D-mannopyranoside, $N$-acetylglucosamine, trehalose, inulin, xylitol, D-lyxose, Dtagatose, D- or L-fucose, D- or L-arabitol or 2-or 5-ketogluconate. +, Positive; -, negative; w, weakly positive.

\begin{tabular}{|c|c|c|c|c|}
\hline Characteristics & 1 & 2 & 3 & 4 \\
\hline \multicolumn{5}{|l|}{ Acid production from: } \\
\hline L-Arabinose & + & + & - & + \\
\hline D-Ribose & + & - & - & + \\
\hline D-Xylose & - & - & - & + \\
\hline D-Galactose & + & + & - & + \\
\hline D-Fructose & - & $\mathrm{w}$ & + & + \\
\hline D-Mannose & - & $\mathrm{w}$ & - & - \\
\hline L-Sorbose & - & - & - & $\mathrm{w}$ \\
\hline Amygdalin & + & - & - & + \\
\hline Arbutin & $\mathrm{w}$ & - & - & + \\
\hline Salicin & + & - & - & + \\
\hline Cellobiose & + & - & - & + \\
\hline Lactose & + & + & - & + \\
\hline Melibiose & + & + & - & + \\
\hline Melezitose & - & - & - & + \\
\hline Raffinose & + & + & - & + \\
\hline Starch & + & $\mathrm{w}$ & + & - \\
\hline Glycogen & + & + & + & - \\
\hline$\beta$-Gentiobiose & + & - & - & + \\
\hline Gluconate & $\mathrm{w}$ & - & - & $\mathrm{w}$ \\
\hline Aesculin hydrolysis & + & + & - & + \\
\hline \multicolumn{5}{|l|}{ Growth at: } \\
\hline $15^{\circ} \mathrm{C}$ & $\mathrm{W}$ & - & - & + \\
\hline $20{ }^{\circ} \mathrm{C}$ & + & + & $\mathrm{W}$ & + \\
\hline $35^{\circ} \mathrm{C}$ & + & $\mathrm{w}$ & + & + \\
\hline $37^{\circ} \mathrm{C}$ & + & - & + & + \\
\hline $40{ }^{\circ} \mathrm{C}$ & - & - & + & + \\
\hline $42{ }^{\circ} \mathrm{C}$ & - & - & $\mathrm{w}$ & - \\
\hline Peptidoglycan type & L-Lys-D-Asp & L-Lys-D-Asp & L-Lys-L-Ser & L-Lys-L-Ser-D-Asp \\
\hline DNA G $+C$ content $(\mathrm{mol} \%)$ & 61.1 & 61.9 & 61.1 & 56.9 \\
\hline
\end{tabular}


aminoquinolyl- $\mathrm{N}$-hydroxysuccinimidylcarbamate; Waters) as the derivatization.

Various phenotypic characteristics of the novel strains differed from those of $B$. minimum YIT $4097^{\mathrm{T}}$ and $B$. psychraerophilum YIT $11814^{\mathrm{T}}$, the phylogenetically closest related type strains (Table 1). According to the data obtained, the two strains are genetically distinguishable from recognized species of bifidobacteria and thus represent a novel species, for which we suggest the name Bifidobacterium mongoliense sp. nov.

\section{Description of Bifidobacterium mongoliense sp. nov.}

Bifidobacterium mongoliense (mon.go.li.en'se. N.L. neut. adj. mongoliense pertaining to Mongolia, from where the type strain was isolated).

Cells grown in modified GAM broth are rods of various shapes, $0.4-0.6 \times 0.8-2 \mu \mathrm{m}$, with rounded or tapered ends, sometimes curved, swollen and branched. They are Grampositive-staining, non-motile, asporogenous, F6PPK-positive, catalase- and oxidase-negative and facultatively anaerobic. Pinpoint colonies $(0.2-0.4 \mathrm{~mm}$ in diameter) are formed under aerobic conditions after 2 days incubation at $30{ }^{\circ} \mathrm{C}$. After anaerobic growth at $30{ }^{\circ} \mathrm{C}$ for $5-6$ days, colonies on modified GAM agar are $2-3 \mathrm{~mm}$ in diameter; they are convex, white, opaque, smooth and circular with entire edges. The temperature range for growth is $15-35^{\circ} \mathrm{C}$; no growth occurs at 10 or $40{ }^{\circ} \mathrm{C}$. The optimum temperature for growth is $25-30{ }^{\circ} \mathrm{C}$. Grows at $\mathrm{pH} 4.5-8.0$ with an optimum at $\mathrm{pH}$ 6.5-7.0. Acid is produced from $\mathrm{L}$-arabinose, D-galactose, D-glucose, maltose, lactose, melibiose, raffinose, starch, glycogen, turanose, methyl $\alpha$-D-glucopyranoside and sucrose. Acid is not produced from glycerol, erythritol, Darabinose, $\mathrm{D}$ - or L-xylose, $\mathrm{D}$-adonitol, methyl $\beta$-D-xylopyranoside, D-fructose, D-mannose, L-sorbose, L-rhamnose, dulcitol, inositol, D-mannitol, D-sorbitol, methyl $\alpha$-Dmannopyranoside, $\mathrm{N}$-acetylglucosamine, trehalose, inulin, melezitose, xylitol, D-lyxose, D-tagatose, D- or L-fucose, D- or $\mathrm{L}$-arabitol or 2- or 5-ketogluconate. Acid production from D-ribose, amygdalin, arbutin, salicin, cellobiose, $\beta$-gentiobiose and gluconate is strain-dependent. Aesculin is hydrolysed. Peptidoglycan structure is L-Lys-D-Asp type with the presence of Lys, Glu, Ala and Asp. The DNA G + C content of the type strain is $61.1 \mathrm{~mol} \%$. Phylogenetic analysis of the $16 \mathrm{~S}$ rRNA gene sequence places the species in the B. minimum subgroup of bifidobacteria.

The type strain, YIT $10443^{\mathrm{T}}\left(=\mathrm{JCM} \quad 15461^{\mathrm{T}}=\mathrm{DSM}\right.$ $21395^{\mathrm{T}}$ ), and the reference strain YIT 10738 were isolated from airag, a traditional fermented mare's milk product, which was collected in the Mongolian provinces of Umnugobi and Uburhangai, respectively, in 2004.

\section{Acknowledgements}

We thank Minoru Ando (Yakult Central Institute) and Masako Nishimura (Hitachi High-Technologies) for their technical assistance with scanning electron microscope observation. We also thank Hiroshi Sakon (Yakult Central Institute) for his technical assistance in analysing peptidoglycan structure.

\section{References}

Cavalli-Sforza, L. L. \& Edwards, A. W. F. (1967). Phylogenetic analysis models and estimation procedures. Am J Hum Genet 19, 233-257.

Chao, S.-H., Tomii, Y., Sasamoto, M., Fujimoto, J., Tsai, Y.-C. \& Watanabe, K. (2008). Lactobacillus capillatus sp. nov., a motile bacterium isolated from stinky tofu brine. Int J Syst Evol Microbiol 58, 2555-2559.

Chun, J., Lee, J.-H., Jung, Y., Kim, M., Kim, S., Kim, B. K. \& Lim, Y. W. (2007). EzTaxon: a web-based tool for the identification of prokaryotes based on $16 \mathrm{~S}$ ribosomal RNA gene sequences. Int J Syst Evol Microbiol 57, 2259-2261.

Dong, X., Xin, Y., Jian, W., Liu, X. \& Ling, D. (2000). Bifidobacterium thermacidophilum sp. nov., isolated from an anaerobic digester. Int $J$ Syst Evol Microbiol 50, 119-125.

Ezaki, T., Hashimoto, Y. \& Yabuuchi, E. (1989). Fluorometric deoxyribonucleic acid-deoxyribonucleic acid hybridization in microdilution wells as an alternative to membrane filter hybridization in which radioisotopes are used to determine genetic relatedness among bacterial strains. Int J Syst Bacteriol 39, 224-229.

Felsenstein, J. (1985). Confidence limits on phylogenies: an approach using the bootstrap. Evolution 39, 783-791.

Felsenstein, J. (2007). PHYLIP (phylogeny inference package) version 3.67. Distributed by the author. Department of Genome Sciences, University of Washington, Seattle, USA.

Finegold, S. M., Sutter, V. S. \& Mathisen, G. E. (1983). Normal indigenous intestinal flora. In Human Intestinal Microflora in Health and Disease, pp. 3-31. Edited by D. J. Hentges. New York: Academic Press.

Fitch, W. M. (1971). Toward defining the course of evolution: minimum change for a specific tree topology. Syst Zool 20, 406-416. Fuller, R. (1989). Probiotics in man and animals. J Appl Bacteriol 66, 365-378.

Kitajima, H., Sumida, Y., Tanaka, R., Yuki, N., Takayama, H. \& Fujimura, M. (1997). Early administration of Bifidobacterium breve to preterm infants: randomized control trial. Arch Dis Child Fetal Neonatal Ed 76, F101-F107.

Lee, Y.-K., Nomoto, K., Salminen, S. \& Gorbach, S. L. (1999). Alteration of microecology in human intestine. In Handbook of Probiotics, pp. 183-191. New York: Wiley-Interscience.

Marmur, J. (1961). A procedure for the isolation of deoxyribonucleic acid from microorganisms. J Mol Biol 3, 208-218.

Matsuki, T., Watanabe, K., Fujimoto, J., Kado, Y., Takada, T. \& Tanaka, R. (2004). Quantitative PCR with $16 \mathrm{~S}$ rRNA-gene-targeted species-specific primers for analysis of human intestinal bifidobacteria. Appl Environ Microbiol 70, 167-173.

Mesbah, M., Premachandran, U. \& Whitman, W. B. (1989). Precise measurement of the $\mathrm{G}+\mathrm{C}$ content of deoxyribonucleic acid by highperformance liquid chromatography. Int J Syst Bacteriol 39, 159-167.

Miyake, T., Watanabe, K., Watanabe, T. \& Oyaizu, H. (1998). Phylogenetic analysis of the genus Bifidobacterium and related genera based on 16S rDNA sequences. Microbiol Immunol 42, 661-667.

Moore, W. E. C. \& Holdeman, V. (1974). Human fecal flora: the normal flora of 20 Japanese-Hawaiians. Appl Microbiol 27, 961-979.

Saitou, N. \& Nei, M. (1987). The neighbor-joining method: a new method for reconstructing phylogenetic trees. Mol Biol Evol 4, 406425 . 
Scardovi, V. (1986). Genus Bifidobacterium Orla-Jensen 1924, $472^{\mathrm{AL}}$. In Bergey's Manual of Systematic Bacteriology, vol. 2, pp. 1418-1434. Edited by P. H. A. Sneath, N. S. Mair, M. E. Sharpe \& J. G. Holt. Baltimore: Williams \& Wilkins.

Scardovi, V. \& Trovatelli, L. D. (1974). Bifidobacterium animalis (Mitsuoka) comb. nov. and the "minimum" and "subtile" groups of new bifidobacteria found in sewage. Int J Syst Bacteriol 24, 21-28.

Scardovi, V. \& Zani, G. (1974). Bifidobacterium magnum sp. nov., a large, acidophilic Bifidobacterium isolated from rabbit feces. Int J Syst Bacteriol 24, 29-34.

Schleifer, K. H. \& Kandler, O. (1972). Peptidoglycan types of bacterial cell walls and their taxonomic implications. Bacteriol Rev 36, 407-477.

Simpson, P. J., Ross, R. P., Fitzgerald, G. F. \& Stanton, C. (2004). Bifidobacterium psychraerophilum sp. nov. and Aeriscardovia aeriphila gen. nov., sp. nov., isolated from a porcine caecum. Int J Syst Evol Microbiol 54, 401-406.
Thompson, J. D., Gibson, T. J., Plewniak, F., Jeanmougin, F. \& Higgins, D. G. (1997). The CLUSTAL_X Windows interface: flexible strategies for multiple sequence alignment aided by quality analysis tools. Nucleic Acids Res 25, 4876-4882.

Ventura, M., Canchaya, C., Del Casale, A., Dellaglio, F., Neviani, E., Fitzgerald, G. F. \& van Sinderen, D. (2006). Analysis of bifidobacterial evolution using a multilocus approach. Int J Syst Evol Microbiol 56, 2783-2792.

Watanabe, K., Fujimoto, J., Sasamoto, M., Dugersuren, J., Tumursuh, T. \& Demberel, S. (2008). Diversity of lactic acid bacteria and yeasts in Airag and Tarag, traditional fermented milk products of Mongolia. World J Microbiol Biotechnol 24, 1313-1325.

Wayne, L. G., Brenner, D. J., Colwell, R. R., Grimont, P. A. D., Kandler, O., Krichevsky, M. I., Moore, L. H., Moore, W. E. C., Murray, R. G. E. \& other authors (1987). International Committee on Systematic Bacteriology. Report of the ad hoc committee on reconciliation of approaches to bacterial systematics. Int J Syst Bacteriol 37, 463-464. 